Geological Society, London, Special Publications

\title{
Silurian-Permian palaeocontinental reconstructions and circum-Atlantic tectonics
}

D. V. Kent and J. D. Keppie

Geological Society, London, Special Publications 1988, v.38; p469-480.

doi: 10.1144/GSL.SP.1988.038.01.30

$\begin{array}{ll}\begin{array}{l}\text { Email alerting } \\ \text { service }\end{array} & \begin{array}{l}\text { click here to receive free e-mail alerts when } \\ \text { new articles cite this article }\end{array} \\ \text { Permission } & \begin{array}{l}\text { click here to seek permission to re-use all or } \\ \text { part of this article }\end{array} \\ \text { request } & \begin{array}{l}\text { click here to subscribe to Geological Society, } \\ \text { Subscribe }\end{array} \\ \text { Condon, Special Publications or the Lyell } \\ \text { Collection }\end{array}$

Notes

(C) The Geological Society of London 2012

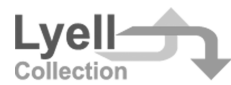




\title{
Silurian-Permian palaeocontinental reconstructions and circum-Atlantic tectonics
}

\author{
D. V. Kent \& J. D. Keppie
}

\begin{abstract}
SUMMARY: On the basis of the palaeomagnetic record, supplemented by constraints provided by faunal and tectonic information, reconstructions involving Laurentia, Baltica, Gondwana and numerous continent-like fragments and terranes within the circum-Atlantic Palaeozoic orogenic belts are made for three critical time intervals, late Silurian, early Carboniferous and late Carboniferous-early Permian, all of which bracket important phases of tectonic activity. The late Caledonian-Scandian-Acadian-Ligerian orogenies are due to the predominantly E-W final closure of Iapetus. This phase was followed in mid-Devonian times by a major sinistral megashear along the orogen which eliminated latitudinal separations and resulted in a Pangea-like assembly by the latest Devonian. The final phase involved a rotation of Gondwana with respect to the assembled Euramerican landmass, expressed as late Variscan-Hercynian dextral shear from central Europe to northeastern $\mathbf{N}$ America and culminating in the late Carboniferous-Permian Alleghanian orogeny in the Appalachians from New England S and in the Mauritanides.
\end{abstract}

The Caledonide-Hercynide-Mauritanide-Appalachian orogenic belts can be considered to be the result of the multistage interaction of three major surrounding cratonic areas (Laurentia, Baltica and Gondwana) and numerous continentlike fragments and terranes (Dewey 1983, Keppie 1984). We concentrate here on the time interval late Silurian to Permian and seek to account for the major tectonic activity in terms of changes in the relative position of these areas as interpreted primarily from the palaeomagnetic record because geological parameters allow too many alternative reconstructions to be useful. Much of the palaeomagnetic data from the Atlanticbordering land areas are reviewed by Briden $e t$ al. (1988) and our interpretations generally conform to their assessments of data reliability.

In the sequence of reconstructions outlined below it has been necessary to make a number of simplifications owing to the unequal spatial and temporal distribution of what are believed to be the most reliable data. Documentation of terranes is at an early stage, and since palaeomagnetic data are generally lacking for most individual terranes they have been conservatively placed in their present relative locations although they may eventually be shown to have separate histories. However, it has become evident that some discrepant palaeomagnetic directions are due to previously unrecognized secondary magnetizations. Despite considerable study, there is still a surprising amount of uncertainty in the apparent polar wander (APW) paths of the major cratonic areas, notably Laurentia and Gondwana, and also Baltica if Britain is not included within it. Hence the time progression and amount of total closure across the orogenic belts are known only in very broad terms. It also follows that the arrangement of terranes that lie within the orogens with respect to the major bordering cratonic areas is imprecisely known.

After having carefully screened the available palaeomagnetic data and using only the best palaeopoles we suggest a working hypothesis for the APW of the Atlantic-bordering continents (except for Gondwana where there are insufficient data). This shows comparatively rapid shifts in palaeopole positions, separating time intervals in which the poles tend to group for the various continental areas. These APW shifts or drift episodes (Briden 1967) roughly correspond to phases of latitudinal adjustments of the landmasses, whereas the apparently static APW intervals allow closure of only longitudinal oceans. Palaeopoles appear to cluster for the intervals late Silurian (Fig. 1), early Carboniferous (Fig. 2) and late Carboniferous-early Permian (Fig. 3). The corresponding reconstructions span the time interval during which the various phases of deformation attributed to the Acadian-late Caledonian and Alleghanian-Hercynian orogenic events took place. Constraints on the relative positions of the landmasses provided by the palaeomagnetic record are supplemented where possible by faunal province and tectonic data.

\section{Constraints on late Silurian reconstruction}

We now believe that the late Silurian is the youngest time interval in the Palaeozoic for which large separations or offsets of the constituent 


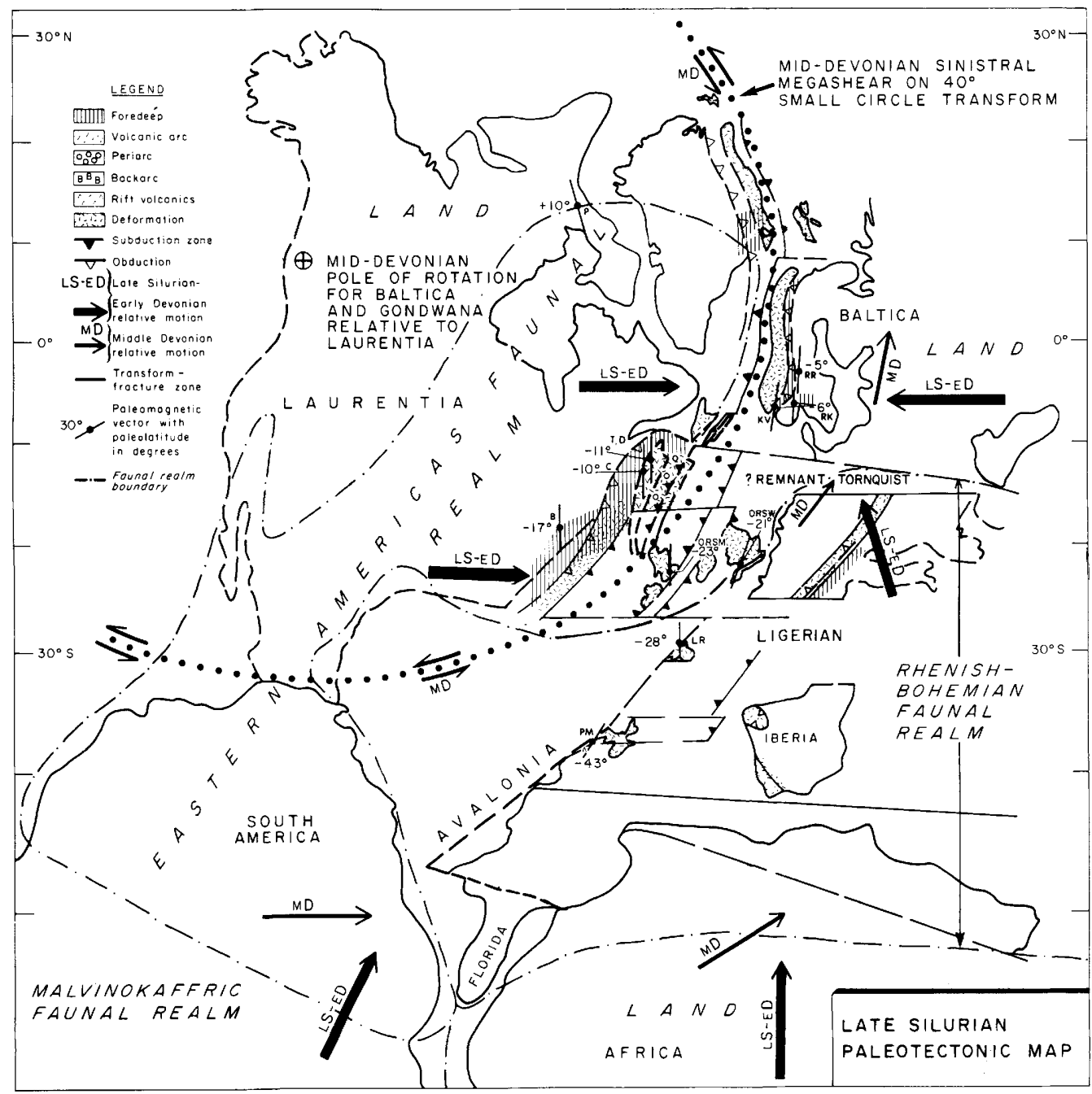

FIG. 1. Palaeocontinental reconstruction for the late Silurian showing the major tectonic elements of the late Caledonian orogen and the distribution of faunal realms (Gray \& Boucot 1979). Representative palaeomagnetic data used to constrain the position of the continental areas are as follows. Laurentia: B, Bloomsburg; P, Peel Sound; T, Traveller; C, Compton; D, Dockendorff. Baltica: KV, Kvamshesten; RR, Roragen; RK, Ringerike. Britain: ORSM, Midland Valley Old Red Sandstone lavas; ORSW, lower Old Red Sandstone, Wales/England. Avalon: PM, Pembroke; LR, Lawrenceton. The position of Africa-S America is based on Mereenie sandstone from Australia (Embleton 1972).

components of the circum-Atlantic Pangean assembly (Bullard et al. 1965) can be convincingly demonstrated by palaeomagnetic means. Therefore this critical interval, the oldest considered here, sets the stage for the pattern of closure and related major tectonic activity in the subsequent time periods.

\section{Baltica}

Baltica is positioned according to consistent but early palaeomagnetic data from Old Red Conti- nent facies rock units in Norway and Sweden (RK, KV, RR in Fig. 1). However, no field evidence to constrain magnetization age is available for these early results, and because the poles tend to fall on younger parts of the British APW path the magnetizations may be contaminated by secondary components. It is therefore not clear whether, following Briden et al. (1973), the palaeomagnetic data from Baltica can be accepted at face value. However, we note that the near-equatorial position for Baltica in the 


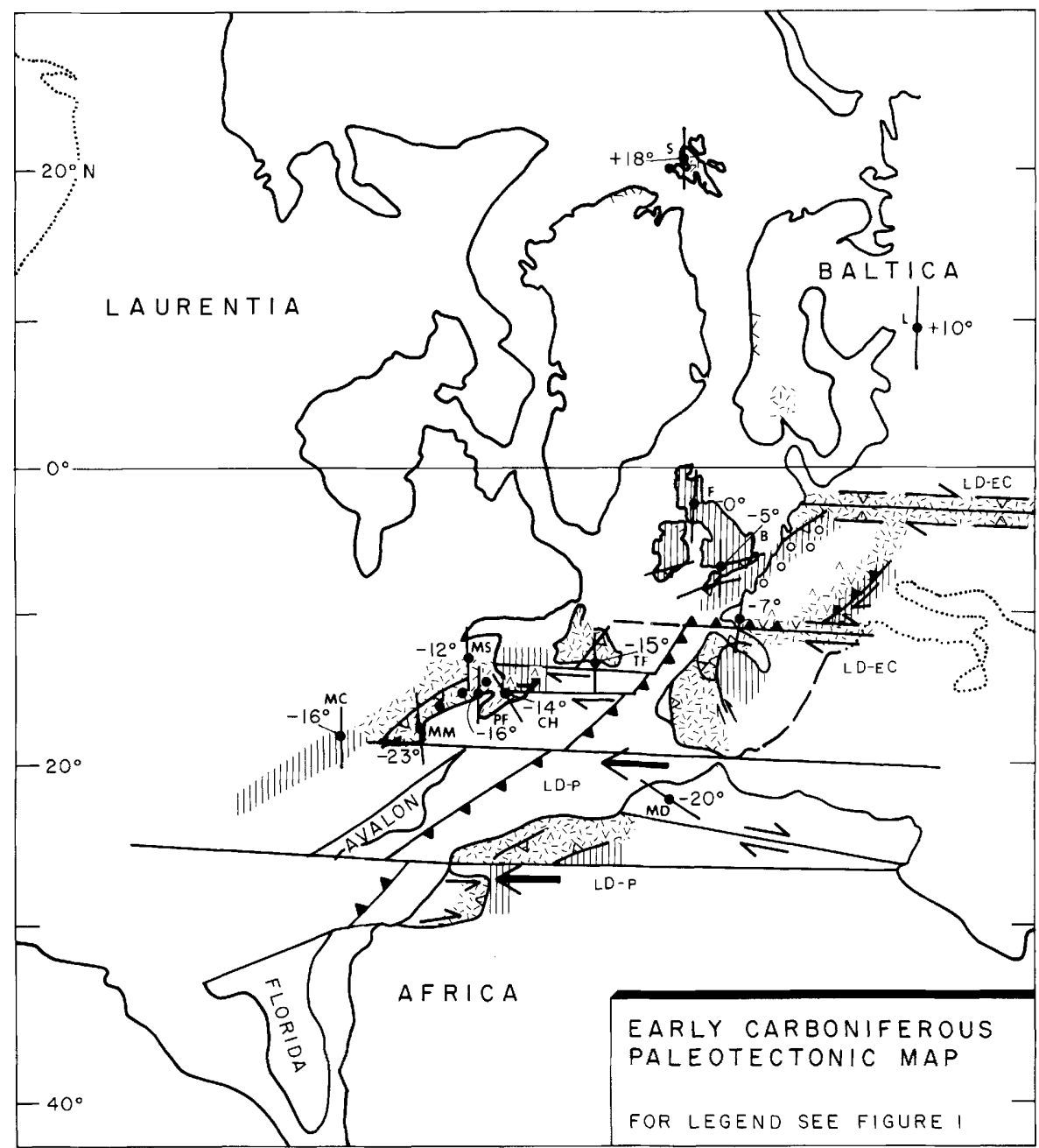

FIG. 2. Early Carboniferous palaeocontinental reconstruction, with representative palaeomagnetic data used to constrain continental positions: MC, Mauch Chunk; MS, Mapleton; PF, Perry sediments and lavas; MM, Massachusetts metavolcanics; TF, Terrenceville; M, Maringoin; $\mathrm{CH}$, Cheverie; S, Svalbard sediments; F, Foyers middle Old Red Sandstone; B, Bristol upper Old Red Sandstone; L, Leningrad; MD, Moroccan sediments and lavas.

Siluro-Devonian suggested by these data is supported by the equatorial-zone Devonian spores recovered from the Old Red Continent facies in southern Scandinavia (McGregor 1979).

\section{Laurentia}

The late Silurian-early Devonian palaeolatitudinal position for Laurentia was formerly based only on palaeomagnetic results (normal and reverse polarities and the positive fold test (Roy et al. 1967)) from the upper Silurian Bloomsburg Formation (B, Fig. 1). These data are now generally supported by the most representative results from the lower Devonian Peel Sound Formation (PS, Fig. 1) of Arctic Canada (Dankers 1982) and indirectly by a set of systematically abberrant directions from lower Devonian rock units from what is referred to as the Traveller terrane of the northern Appalachians (T, C, D, Fig. 1). The Traveller directions, which include a positive fold test and reversals, are compatible in palaeolatitude with Laurentia but, because of a significant deviation in declination compared with the Bloomsburg Formation (and also the Peel Sound), are thought to reflect a subsequent 


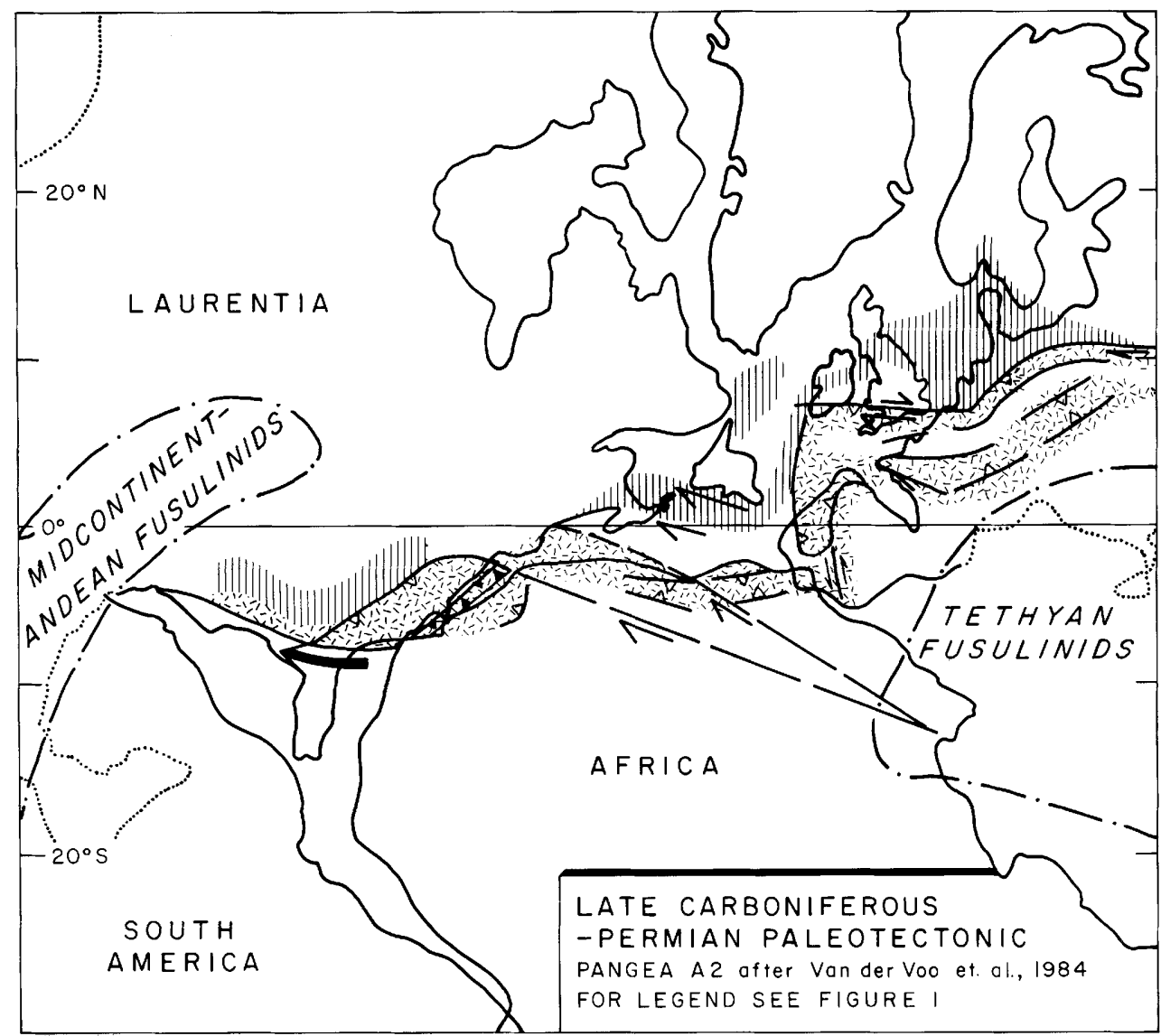

FIG. 3. Late Carboniferous to Permian palaeocontinental reconstructions corresponding to the Pangea A2 model (Van der Voo et al. 1984). Fusilinid faunal provinces from Ross (1979).

clockwise tectonic rotation of the Traveller terrane against stable N America (Spariosu \& Kent 1983). Together these palaeomagnetic data place Laurentia as straddling the equator and are consistent with the presence of low-latitude upper Silurian-lower Devonian lithologies (such as carbonates and evaporites) and the associated Appohimchi sub-province of the Eastern Americas Faunal Realm (Boucot 1975).

That Laurentia and Baltica were close together at this time cannot be established by palaeomagnetic means because longitude is indeterminant, but a proximal position is indicated by the appearance of similar freshwater vertebrates on both cratons at the end of the Silurian (Young 1981). However, when compared with a conventional Triassic Euramerican reconstruction (Bullard et al. 1965), the available palaeomagnetic data from Laurentia and Baltica conflict. This conflict remains regardless of whether or not the Baltica directions represent later remagnetization because in neither case do they fall on any younger portion of the Laurentia APW path. We resolve the conflict by placing Baltica offset approximately $15^{\circ} \mathrm{S}$ with respect to Laurentia (Fig. 1).

\section{Gondwana}

The position of Gondwana is very poorly constrained owing to inadequate palaeomagnetic data. One of the few results that may pertain to an assembled Gondwana (Smith \& Hallam 1970) for this time interval is from the Mereenie Sandstone of central Australia. Although the magnetization history and even the age of the Mereenie is quite uncertain (cited as Silurian?Devonian by Embleton (1972)), the palaeopole 


\section{Silurian-Permian palaeocontinental reconstructions and circum-Atlantic tectonics}

reassuringly falls near the terminus of the betterdocumented lower Palaeozoic APW path for Gondwana (Embleton et al. 1974). A variety of APW paths can be drawn through Silurian and Devonian palaeopoles obtained from southeastern Australia (Schmidt \& Morris 1977, Morel \& Irving 1978, Goleby 1980), but they may reflect tectonic movements in the Tasman orogen rather than drift of all Gondwana (Embleton et al. 1974). In view of the lack of definitive palaeomagnetic data to the contrary, we position Gondwana according to the Mereenie palaeopole constraint with Africa centred over the S pole. This is consistent with the presence of the coldwater Malvinokaffric Faunal Realm in the early Devonian rocks of southern S America and S Africa (Boucot 1975). At the same time the presence of the Amazon-Colombian brachiopod sub-province in northern S America, which has strong affinities with the Appohimchi sub-province (Boucot 1975), suggests proximity between $\mathrm{N}$ and $\mathrm{S}$ America which is satisfied by the arrangement shown in Fig. 1.

\section{Terranes}

Old Red Continent rocks from British terranes tend to give concordant palaeomagnetic results that place them in moderate southerly palaeolatitudes. Representative of the late Silurian-early Devonian palaeopole position for two terranes on either side of the Iapetus suture in Britain are results from the Midland Valley Old Red Sandstone lavas (ORSM) and the lower Old Red Sandstone of Wales/England (ORSW) which suggest palaeolatitudes in the $20-25^{\circ} \mathrm{S}$ range. These and similar late Silurian and early Devonian palaeomagnetic results from other British terranes (Briden et al. 1973, 1984) suggest that there is not much latitudinal separation between them. This is consistent with the conclusions of Bluck (1983) and of Mitchell \& McKerrow (1975). However, these British data are not compatible with those taken at face value from either Baltica or Laurentia in a conventional Euramerican assembly. These data show a latitudinal offset of Laurentia on one side and Baltica and southern Britain on the other, and less clearly between Baltica and Britain.

This reconstruction neatly suggests that the Scottish Siluro-Devonian volcanic arc was a continuation of the Traveller volcanic arc terrane (Fig. 1), but this appears to create problems in explaining the location of the Archaean Scourian basement adjacent to the Grenville basement of $\mathrm{N}$ America. However, it has been suggested that Baltica lay adjacent to eastern $\mathrm{N}$ America during the latest Precambrian (Ueno et al. 1975, Patchett \& Bylund 1977). Therefore it is possible that the Scourian basement is correlated with the preKarelian basement in Baltica and was a fragment left behind in the early Palaeozoic only to be transported later, in the Devonian, to more or less its present position relative to Baltica.

Siluro-Devonian palaeopoles from the Avalon composite terrane in the northeastern Appalachians suggest a location between 28 and $43^{\circ} \mathrm{S}$. This is based on palaeomagnetic data from the uppermost Silurian Pembroke Formation (PM, Fig. 1) (cited by Roy \& Anderson (1981) as the most reliable result in their study of the Mascarene Group of coastal New Brunswick) and from the Lawrenceton rhyolite of central Newfoundland (LR, Fig. 1) (supported by a positive fold test (Lapointe 1979)). The palaeolatitudinal position of the Avalon composite terrane is therefore consistent with a Siluro-Devonian position relative to Britain as seen in a Pangea fit. The somewhat shallower inclinations (lower palaeolatitudes) obtained from some other SiluroDevonian rock units in Avalonia may imply that these units have younger (reset?) magnetization ages, whereas the generally much steeper but scattered directions reported from some Devonian igneous intrusions in the northern Appalachians are intrinsically problematical with regard to their tilt correction and may be of only local significance (Kent \& Opdyke 1982, Roy 1982).

Southern Britain and Avalonia are thought to be part of a larger continental-like mass, Armorica, which formally includes the Hercynian Massif (Andreeva et al. 1965) give a palaeolatitude of about $25^{\circ} \mathrm{S}$, which is compatible with this arrangement at least in terms of closely associated tectonic elements. The proximity of these terranes to one another and to adjacent cratons is also suggested by their common impoverished Rhenish-Bohemian fauna which extended onto the marginal areas of $\mathbf{N}$ and $\mathbf{S}$ America and Africa (Boucot 1975). Thus the Armorica assemblage was probably distributed around a small ocean basin with restricted circulation and high evaporation rates, consistent with the $30^{\circ} \mathrm{S}$ palaeolatitudinal belt suggested by the palaeomagnetic evidence (Fig. 1).

\section{Constraints on early Carboniferous reconstruction}

There is increasing agreement that Euramerica, consisting of Baltica, Laurentia, Britain and 
other parts of the Armorica mosaic, was essentially assembled by the end of the Devonian. However, the relationship between Euramerica and Gondwana at this time is less certain.

\section{Euramerica}

According to late Devonian palaeomagnetic data from the Leningrad area (L, Fig. 2) (summarized by Van der Voo \& Scotese 1981), Baltica is placed between the equator and $20^{\circ} \mathrm{N}$; a similar position is suggested for the early Carboniferous Svalbard sediments (S, Fig. 2). This location is supported by the presence of the equatorial Lepidodendropsis fauna (Chaloner \& Lacey 1973) and the restricted distribution of Archaeoperisaccus spores to the belt $\mathrm{N}$ of the Devonian equator (McGregor 1979).

Formerly, the best palaeomagnetic results (with positive fold tests) from upper Devonian (Catskill Formation (Van der Voo et al. 1979)) and lower Carboniferous (Mauch Chunk Formation (Knowles \& Opdyke 1968)) rock units from Laurentia placed it in equatorial latitudes, but still offset by about $15^{\circ}$ or $2000 \mathrm{~km}$ to the $\mathrm{N}$ with respect to Baltica and the continental-like Armorica assemblage. However, it can now be shown that the Laurentia reference poles for at least the early Carboniferous on which this interpretation partly rested were not sufficiently demagnetized and thus are partly due to later (Permo-Carboniferous) magnetization overprints (Roy \& Morris 1983, Irving \& Strong 1984, Kent \& Opdyke 1985). The new results (MC and DL, Fig. 2) from complete demagnetization analysis pass the fold test and place Laurentia about $15^{\circ}$ farther to the $S$ in the early Carboniferous, a position similar to the late Silurian but which is now in accord with Armorica-AvalonBritain and Baltica palaeomagnetic data (TF, M, S, B, AM and L, Fig. 2) on a Pangea model. Palaeomagnetic results from the middle and upper Devonian rocks of the Traveller terrane are consistent in both palaeolatitude and meridional orientation with these new early Carboniferous data (Spariosu \& Kent 1984). In this light, the Catskill pole is anomalous and, indeed, recent results from a restudy of the Catskill indicate that the reported directions are secondary (Miller \& Kent 1985). Furthermore, discordant data from $\mathrm{N}$ of the Great Glen Fault, which is considered as evidence for a major (about $2000 \mathrm{~km}$ ) late Devonian offset across it (Van der Voo \& Scotese 1981), are now being interpreted as secondary magnetizations of Permian, Mesozoic or Tertiary age (Briden et al. 1984, Cisowski 1984).

Therefore a coherent Euramerica assembly with no major internal offsets, closely resembling the geometrical fit described by Bullard et al. (1965), is suggested by this time (Fig. 2). Minor documented exceptions are from Carboniferous directions for the Meguma in southern Nova Scotia (Spariosu et al. 1984) and for central Europe (Bachtadse et al. 1983) which show evidence of rotations about local vertical axes. The revised early Carboniferous location for Laurentia is consistent with its being part of the Old Red Continent with its cosmopolitan flora such as Retispore lepidophyta and its distinct Archaeoperisaccus spores confined to Hudson's Bay, southern Greenland and southern Scandinavia (McGregor 1979).

\section{Gondwana}

Palaeomagnetic data available from Gondwana at present lend themselves to two different interpretations (Kent et al. 1984): either Africa remained centred over the $\mathrm{S}$ pole (on the basis of results from the Msissi norite of Morocco) or, according to the remanence directions from Gneiguira sediments from Mauritania, its northern margin had already migrated to moderate southern latitudes by this time. The age and tectonic setting of the Msissi norite is not well described in the report on the palaeomagnetism of the unit (Hailwood 1974). However, no field tests are available to constrain the magnetization age of the hematite remanence of the Gneiguira (Kent et al. 1984) and post-Devonian remagnetization cannot be excluded. Hence the interpretation is ambiguous.

The first possibility, based on the Msissi data, implies the development of a large ocean between Gondwana and the more equatorial Euramerican assembly (Jones et al. 1979); the large ocean created must then have been rapidly consumed because there is general agreement (Schmidt \& Morris 1977, Morel \& Irving 1978) that the facing margins of Gondwana (Africa-South America) were already in low palaeolatitudes by the early Carboniferous. The second possibility, suggested by the Gneiguira data, does not require independent Armorican and Gondwana plates but allows them to remain generally contiguous. This requires neither the creation nor the rapid consumption of a large late Devonian ocean. At present we favour the second option (Fig. 2) and note that a proximal position for Gondwana with respect to Euramerica is supported by the dispersal of freshwater vertebrates between these areas during the late Devonian (Young 1981) and the highly cosmopolitan marine fauna when no biogeographic realms can be distinguished (Bou$\cot \&$ Gray 1983). 


\section{Constraints on late Carboniferous- Permian reconstruction}

The late Carboniferous-Permian reconstruction (Fig. 3) used in this paper is model A2 of Van der Voo et al. (1976). We prefer the Pangea A2 model to the Pangea B model of Irving (1977) because, among other factors, the former better satisfies the geographic distribution of Permian fusilinid faunal provinces (Ross 1979). We also consider it more than a coincidence that model A2 is near to the model of closure derived from totally independent evidence from the Atlantic ocean floor and margins (Klitgord \& Schouten 1982). Thus we would suppose that Pangea in approximately the A2 configuration persisted essentially from about the late Carboniferous until the opening of the modern Atlantic Ocean in the middle Jurassic. In contrast, the Pangea $B$ model would necessitate a major reorganization, with extravagant relative movements of the order of $3500 \mathrm{~km}$ in the Mesozoic for which geological evidence is difficult to find, in order to achieve the Jurassic pre-drift configuration. A full discussion of the palaeomagnetic evidence bearing on these and other Pangea models is given by Van der Voo et al. (1984).

\section{Evolution of the orogen}

The three palinspastic maps (Figs 1-3) provide bases on which to plot the appropriate palaeotectonic elements, which in turn form the basis for a tectonic model for the orogen between Silurian and Permian times. This method was used by Keppie (1977) and is followed here in historical sequence. The polarity of subduction is derived not only from volcanic arc complexes but also from the polarity of obduction with which it is parallel.

\section{Late Silurian-early Devonian}

In order to understand the genesis of the orogen at this time it is necessary to review briefly the earlier movements of the three major cratonic areas: Laurentia, Baltica and Gondwana. During the early Palaeozoic Laurentia and Baltica occupied low palaeolatitudes, in contrast with Gondwana which was located at high palaeolatitudes (Briden et al. 1988). Similar late PrecambrianOrdovician APW paths derived for both Armorica and Gondwana imply that these areas were attached or closely associated during this time interval (Hagstrum et al. 1980, Perigo et al. 1983,
Perroud \& Van der Voo 1985). Similar evidence is accumulating that the Avalon, Meguma (at least the Piedmont of Delaware) and peninsular Florida areas of eastern $\mathbf{N}$ America were also once part of Armorica and/or Gondwana (Rao \& Van der Voo 1980, Johnson et al. 1983, Jones et al. 1983).

During the Silurian, Gondwana with Armorica (including Avalonia and southern Britain) evidently moved northward. These relative motions between Gondwana, Laurentia and Baltica included the closure of Iapetus. The convergence between Baltica and Laurentia led to the obduction of the Scandinavian and Greenland Caledonide nappes during the Silurian and early Devonian Scandian orogeny with the development of foredeep clastic wedges (Hurst \& McKerrow 1981, Gee \& Roberts 1983). The direction of obduction suggests that boith eastern Greenland and western Scandinavia were on the subducting plate. At first glance this appears contradictory, but it should be noted that these two areas were not opposite one another at this time (Fig. 1). A transform fault between the subduction zones with opposing polarities is therefore inferred.

Farther $\mathrm{S}$ along the orogen, in the northern Appalachians, the convergence was marked by the following events: (i) the extensive SiluroDevonian Acadian overthrusting in central Newfoundland and intermediate pressure metamorphism in the Gander Zone, implying southeasterly obduction (Karlstrom et al. 1982, Colman-Sadd \& Swinden 1984); (ii) the development of a Siluro-Devonian volcanic arc through eastern Gaspé and northern Maine (Osberg 1978) indicative of northwestward subduction; (iii) intermediate pressure metamorphism associated with northwestward obduction in southern New England; (iv) the Siluro-Devonian peripheral bulge unconformity followed by the late Devonian-early Carboniferous Catskill-Pocono clastic wedge, inferred to have accompanied the northwestward emplacement of nappes in the central Appalachians (Thomas 1977, Quinlan \& Beaumont 1984). The opposite polarity between the Gaspé-Maine volcanic arc and the southern New England-central Appalachian region suggests a complex microplate geometry with transform faults separating regions of opposite polarity (Fig. 1).

In the British Isles the convergence is recorded by (i) the late Ordovician-Silurian accretionary wedge in the Southern Uplands of Scotland and the volcanic arc complex in the Midland Valley and Highlands of Scotland (Bluck 1983, McKerrow 1988), implying northwesterly subduction, and (ii) volcanic arc complexes in England, 
Wales and SE Ireland, indicating southeasterly subduction (Stillman \& Francis 1979). Palaeomagnetic data show that Iapetus was basically closed by the end of the Silurian (Briden et al. 1984) (Fig. 1).

In western Europe the effects of convergence are recorded by Siluro-Devonian calc-alkalic volcanism, deformation and metamorphism, although the polarity is rather uncertain at this time and may have involved complex microplate interactions (Bard et al. 1980, Matte 1983, Ziegler 1984). In Avalonia, the effects are limited to weak to moderate deformation (Keppie et al. 1982).

\section{Mid-Devonian}

The collision of Baltica and Laurentia by the early Devonian evidently choked the subduction zone(s) and the $\mathrm{E}-\mathrm{W}$ component of convergence ceased. Plate motions were reorganized and the northward component of motion of Gondwana and also Baltica became dominant. Comparison of Figs 1 and 2 reveals that, while Laurentia remained essentially stationary, Gondwana, Baltica and the elements of Armorica all moved northward by between $15^{\circ}$ and $30^{\circ}$. This motion can be resolved on a sinistral megashear coinciding with a small circle with a centre in northwestern $\mathbf{N}$ America (Fig. 1). Evidence for this megashear relies heavily upon palaeomagnetic data for the postulated megashear presumably lies offshore along most of its length. In the light of the discoveries of the effects of secondary magnetizations where they were taken as primary in the upper Devonian and lower Carboniferous rock record of Laurentia and northern Britain, the same reanalysis is probably necessary for the Siluro-Devonian poles. Nevertheless, the most reliable palaeomagnetic data suggest such a sinistral megashear in the mid-Devonian. Geological evidence for mid-Devonian sinistral transcurrent faulting along the trend of the proposed megashear can be found in Svalbard (Harland 1969, 1984) and in the Gander Zone of Newfoundland (Hanmer 1981). Farther S along the Fredericton Trough only dextral motions have been observed (Ludman \& Morisi 1984). However, these may be younger and, if superposed on earlier fabrics, may obscure the earlier sense of motion.

The northward movement of Baltica appears to have initiated convergence and subduction along its northeastern margin in the western Urals (Hamilton 1970). Some of the sinistral megashear was taken up by convergence across the Ligerian-Variscan orogens (Cogne \& Lefort 1984) and possibly across a remnant Tornquist (Fig. 1).

\section{Late Devonian-Permian}

By the late Devonian, Pangea was close to being assembled (Fig. 2) although subduction accompanied by dextral transcurrent faulting (Pique 1983, Francis 1988) and thrusting occurred in the Moldanubian and N African volcanic arcs. After final closure of Armorica against both Baltica and Laurentia, the movement of Gondwana became decoupled from that of Armorica and it rotated and converged against Laurentia with eastward obduction of the Mauritanide nappes. In the late Carboniferous and early Permian (Fig. 3) this motion of Gondwana with respect to Euramerica created dextral shear in the Hercynides and westward-directed Alleghanian thrusting in the central and southern Appalachians (Arthaud \& Matte 1977), accompanied by the formation of foredeep clastic wedges (Thomas 1977). The direction of obduction suggests a southeasterly-dipping subduction zone. The local tectonic rotations documented for Meguma and central Europe probably also occurred at this time within the broad Hercynian orogenic belt. The Suwanee basin of Florida was $\mathrm{S}$ of a transform boundary and hence suffered little deformation (Nelson et al. 1985). In the Ouachitas deposition of flysch preceded nappe emplacement as the northern part of S America converged with this $S$ central part of Laurentia.

\section{Concluding comments}

The sequence of palaeocontinental reconstructions we propose for the late Silurian to Permian time interval can be regarded as a rather conservative tectonic framework for the evolution of the late Caledonian and Hercynian orogenies. It involves a minimal number of interacting continental elements and terranes, and assumes the least amount of relative movement consistent with a reasonable interpretation of the best available palaeomagnetic, as well as tectonic and faunal, evidence. The relative simplicity of the model also makes critical aspects readily subject to test, especially by further palaeomagnetic work. Further work in the terranes is necessary to document whether they were separate from or closely associated with major continents during the late Palaeozoic.

Our Devonian assembly model for the main elements of Pangea differs from several recent palaeomagnetic models in several notable respects. A critical difference is that major latitudinal oceans had closed by the early to middle Devonian producing the late Caledonian-Scandian-Acadian-Ligerian orogenic events, 
whereas some previous interpretations infer the existence of an ocean several thousand kilometres wide separating Euramerica and Gondwana even later in the Devonian (Kent 1982, Van der Voo 1982). The suggested absence of this wide Devonian ocean allows Armorica to remain closely associated with Gondwana throughout the Palaeozoic.

However, a latitudinal offset between Laurentia on the western side and Armorica-Avalon and Baltica on the eastern side is required to explain the late Silurian-early Devonian palaeomagnetic poles (Morris 1976). Until very recently the best available evidence pointed to a Carboniferous age for motion on a sinistral megashear between eastern and western Euramerica. New palaeomagnetic data from Laurentia (Irving \& Strong 1984, Kent \& Opdyke 1985) now show that there is no major offset in the early Carboniferous and cast serious doubt on its reality for the late Devonian (Irving \& Strong
1985, Miller \& Kent 1885). Instead, major sinistral motion most probably occurred much earlier in the Devonian. The Variscan-Hercynian and Alleghanian orogenies are then apparently due to predominantly dextral shear and E-W closure respectively as Africa-S America rotated westward with respect to Euramerica. The palaeomagnetic signature of this culminating phase of tectonic activity seems to be minor because relative motion occurred predominantly along lines of latitude or about local vertical axes, while Pangea as a whole migrated northward.

ACKNOWLEDGMENTS: We thank the reviewers for offering constructive comments that allowed us to improve the paper. The work was supported by U.S. National Science Foundation Grants EAR82-12549 and EAR85-07046 to DVK and the Department of Mines and Energy, Nova Scotia. This paper is a Lamont-Doherty Geological Observatory contribution.

\section{References}

Andreeva, O. L., Bukha, V. V. \& Petrova, G. N. 1965. Laboratory evaluation of magnetic stability of the Czech Massif. Izvestia Akademii Nauk SSSR, Seriya Geofizicheskaya, 54-64.

ARthaud, F. \& MatTe, P. 1977. Late Paleozoic strike-slip faulting in southern Europe and northern Africa: result of a right-lateral shear zone between the Appalachians and the Urals. Geological Society of America Bulletin, 88, 130520.

Bachtadse, V., Heller, F. \& Kroner, A. 1983. Paleomagnetic investigations in the Hercynian mountain belt of central Europe. Tectonophysics, 91, 185-299.

Bard, J. P., Burg, J. P., Matte, Ph. \& Ribeiro, A. 1980. La chaine hercynienne d'Europe occidentale en termes de tectonique des plaques. Memoire du Bureau de Recherches Géologiques et Minières, 108, 233-46.

BLuck, B. J. 1983. Role of the Midland Valley of Scotland in the Caledonide Orogeny. Transactions of the Royal Society of Edinburgh, Earth Sciences, 74, 119-36.

Boucot, A. J. 1975. Developments in Paleontology and Stratigraphy, Vol. 1, Evolution and Extinction Rate Controls, Elsevier, Amsterdam, 427 pp.

_ \& Gray, J. 1983. A Paleozoic Pangaea. Science, 222, 571-81.

BRIDEN, J. C. 1967. Recurrent continental drift of Gondwanaland. Nature, London, 215, 1334.

, KeNT, D. V., LAPOINTE, P. L., LivermoRe, R. A., Roy, J. L., Seguin, M. K., SMITH, A. G., VAN DER Voo, R. \& Watts, D. R. 1988. Palaeomagnetic constraints on the evolution of the CaledonianAppalachian orogen. This volume.
, Morris, W. A. \& Piper, J. D. A. 1973. Palaeomagnetic studies in the British Caledonides, VI. Regional and global implications. Geophysical Journal of the Royal Astronomical Society, 34, 107 34.

__ Turnell, H. B. \& Watts, D. R. 1984. British paleomagnetism, Iapetus Ocean and the Great Glen Fault. Geology, 12, 428-31.

Bullard, E. C., Everett, J. E. \& Smith, A. G. 1965. A symposium on Continental Drift. IV. The fit of the continents around the Atlantic. Philosophical Transactions of the Royal Society of London, Series $A, \mathbf{2 5 8}, 41-51$.

Chaloner, W. G. \& Lacey, W. S. 1973. The distribution of Late Palaeozoic floras. Special Papers in Palaeontology, 12, 271-289.

Cisowski, S. M. 1984. Evidence for early Tertiary remagnetization of Devonian rocks from the Orcadian, northern Scotland, and associated transcurrent fault motion. Geology, 12, 369-72.

Cogne, J. \& LEFORT, J. P. 1985. The Ligerian Orogeny: a proto-Variscan event related to the SiluroDevonian evolution of the Tethys I Ocean. In: GeE, G. D. \& StuART, B. (eds) The Caledonide Orogen: Scandinavia and Related Areas, 1185-94, Wiley, Chichester.

Colman-SAdD, S. P. \& Swinden, H. S. 1984. A tectonic window in central Newfoundland: geological evidence that the Appalachian Dunnage Zone may be allochthonous. Canadian Journal of Earth Sciences, 21, 1349-67.

DANKeRS, P. 1982. Implications of early Devonian poles from the Canadian Arctic Archipelago for the North American apparent polar wander path. Canadian Journal of Earth Sciences, 19, 1802-9. 
DEWEY, J. F. 1983. Plate tectonics and the evolution of the British Isles. Journal of the Geological Society, London, 139, 371-412.

EMBLEToN, B. J. J. 1972. The Palaeomagnetism of some Palaeozoic sediments from central Australia. Journal and Proceedings of the Royal Society of New South Wales, 105, 86-93.

Embleton, B. J. J., McElhinny, M. W., Crawford, A. R. \& LUCK, G. R. 1974. Palaeomagnetism and the tectonic evolution of the Tasman orogenic zone. Journal of the Geological Society of Australia, 21, 187-93.

Francis, E. H. 1988. Mid-Devonian to early Permian volcanism: Old World. This volume.

GeE, D. G. \& Roberts, D. 1983. Timing of deformation in the Scandinavian Caledonides. NATO ASI Series C, 116, 279-92.

Goleby, B. R. 1980. Early Palaeozoic palaeomagnetism in South East Australia. Journal of Geomagnetism and Geoelectricity, 32, Suppl. SIII, SIII 11, SIII 21.

Gray, J. \& Boucot, A. J. (eds) 1979. Historical Biogeography, Plate Tectonics, and the Changing Environment, Oregon State University Press, Corvallis, $O R$.

Hagstrum, J. T., Van der Voo, R., Auvray, B. \& BONHOMMET, N. 1980. Eocambrian-Cambrian palaeomagnetism of the Armorican Massif, France. Geophysical Journal of the Royal Astronomical Society, 61, 489-517.

HaIlwood, E. A. 1974. Paleomagnetism of the Msissi Norite (Morocco) and the Paleozoic Reconstruction of Gondwanaland. Earth and Planetary Science Letters, 23, 376-86.

Hamilton, W. 1970. The Uralides and the motion of the Russian and Siberian Platforms. Geological Society of America Bulletin, 81, 2553-76.

HANMER, S. 1981. Tectonic significance of the northeastern Gander Zone, Newfoundland : an Acadian ductile shear zone. Canadian Journal of Earth Sciences, 18, 120-35.

Harland, W. B. 1969. Contribution of Spitsbergen to understanding of tectonic evolution of North Atlantic Region. In: KAY, H. (ed.) North AtlanticGeology and Continental Drift, pp. 234-5, American Association of Petroleum Geologists, Tulsa, OK.

— 1985. Caledonide Svalbard. In: GeE, D. G. \& SturT, B. A. (eds) The Caledonide Orogen, Scandinavia and Related Areas, pp. 999-1016, Wiley, Chichester.

Hurst, J. M. \& McKerrow, W. S. 1981. The Caledonian nappes of Kronprins Christian Land, Eastern North Greenland. Rapport Gronlands Geologiske Undersokelse, 106, 15-19.

IRVING, E. 1977. Drift of the major continental blocks since the Devonian. Nature, London, 270, 304-9.

\& Strong, D. F. 1984. Paleomagnetism of the Early Carboniferous Deer Lake Group, western Newfoundland: no evidence for Carboniferous displacement of "Acadia". Earth and Planetary Science Letters, 69, 379-90.

\& - 1985. Paleomagnetism of rocks from Burin Peninsula, Newfoundland: hypothesis of Late Devonian displacement of Acadia criticized. Journal of Geophysical Research, 90, 1949-62.
Johnson, R. J., VAN DER VoO, R. \& KEPPIE, D. 1983. The Paleozoic drift of the Avalon basement terrane of Nova Scotia. EOS, 64, 690 (abstract).

Jones, D. S., Macfadden, B. J., OpdyKe, N. D. \& Smith, D. L. 1983. Paleomagnetism of lower Paleozoic rocks of the Florida basement. EOS, 64 , 690.

JoNes, M., VAN DeR VoO, R. \& BONHOMMET, N. 1979. Late Devonian to early Carboniferous palaeomagnetic poles from the Armorican Massif, France. Geophysical Journal of the Royal Astronomical Society, 58, 287-308.

Karlstrom, D. E., Van der Pluijm, B. A. \& Williams, P. F. 1982. Structural interpretation of the eastern Notre Dame Bay area, Newfoundland: regional post-middle Silurian thrusting and asymmetrical folding. Canadian Journal of Earth Sciences, 19, 2325-41.

Kent, D. V. 1982. Paleomagnetic evidence for postDevonian displacement of the Avalon Platform (Newfoundland). Journal of Geophysical Research, 87, 8709-16. \& OPdYKE, N. D. 1982. Paleomagnetism of SiluroDevonian rocks from eastern Maine: Reply. Canadian Journal of Earth Sciences, 19, 232-7.

\& $\&-1985$. Revised paleomagnetic directions for the lower Carboniferous Mauch Chunk Formation of the central Appalachians and their tectonic implications. Journal of Geophysical Research, 90, 5371-83.

_, Dia, O.\& SougY, J. M. A. 1984. Paleomagnetism of lower-middle Devonian and upper ProterozoicCambrian(?) rocks from Mejeria (Mauritania, West Africa). In: VAN DER Voo, R. et al. (eds) Plate Reconstruction from Paleozoic Paleomagnetism, Geodynamic Series, Vol. 12, pp. 99-115, American Geophysical Union, Washington, DC.

KePPIE, J. D. 1977. Plate tectonic interpretation of Paleozoic world maps. Nova Scotia Department of Mines and Energy Paper 77-3, 41 pp.

1985. The Appalachian collage. In: GEE, D. G. \& STURT, B. (eds) The Caledonide Orogen, Scandinavia and Related Areas, pp 1217-26, Wiley, Chichester.

- , St Julien, P., Hubert, C., Beland, J., Skidmore, B., Rintenberg, A. A., FyfFe, L. R., MCCutcheon, S. R., Williams, H. \& Bursnall, J. 1982. Structural map of the Canadian Appalachians. Memorial University of Newfoundland Map No. 4, Scale 1:1,000,000.

KLITGARD, K. D. \& SCHOUTEN, H. 1982. Early Mesozoic Atlantic reconstructions from seafloor-spreading data. EOS, 63, 307 (abstract).

KNOWLES, R. R. \& OPDYKE, N. D. 1968. Paleomagnetic results from the Mauch Chunk Formation: a test of the origin of curvature in the folded Appalachians of Pennsylvania. Journal of Geophysical Research, 73, 6515-26.

LAPOINTE, P. L. 1979. Paleomagnetism and orogenic history of the Botwood Group and Mount Peyton Batholith, Central Mobile Belt, Newfoundland. Canadian Journal of Earth Sciences, 16, 866-76.

Ludman, A. \& Morisi, L. 1984. Stratigraphic and structural control in eastern Maine. Geological Society of America, Abstracts with Programs, 16, 48. 
MatTe, P. 1983. Two geotraverses across the IberoAmorican Variscan of Western Europe. In: Geodynamic Series, Vol. 10, pp. 53-82, American Geophysical Union, Washington, DC.

MCGREGoR, D. C. 1979. Spores in Devonian stratigraphical correlations. Special Papers in Palaeontology, 23, 163-84.

MCKerRow, W. S. 1988. Wenlock to Givetian deformation in the British Isles and the Canadian Appalachians. This volume.

Miller, J. D. \& Kent, D. V. 1985. Another look at the Catskill. EOS, 66, 257 (abstract).

Mitchell, A. H. G. \& MCKerrow, W. S. 1975. Analogous evolution of the Burma orogen and the Scottish Caledonides. Geological Society of America Bulletin, 86, 305-15.

Morel, P. \& IRVING, E. 1978. Tentative paleocontinental maps for the early Phanerozoic and Proterozoic. Journal of Geology, 86, 535-61.

MORRIS, W. A. 1976. Transcurrent motion determined paleomagnetically in the northern Appalachians and Caledonides and the Acadian orogeny. Canadian Journal of Earth Sciences, 13, 1236-43.

Nelson, D. D., Arnow, J. A., MCBride, J. H., Willemin, J. H., Huang, J., Zheng, L., Oliver, J. E., Brown, L. D. \& Kaufman, S. 1985. New COCORP profiling in the southeastern United States, Part 1, Late Paleozoic suture and Mesozoic rift basin. Geology, 13, 714-18.

OsBERG, P. H. 1978. Synthesis of the geology of the northern Appalachians, U.S.A. Geological Survey of Canada Paper No. 78-13, pp. 127-47.

Patchett, P. J. \& Bylund, G. 1977. Age of Grenville Belt magnetisation: $\mathrm{Rb}-\mathrm{Sr}$ and palaeomagnetic evidence from Swedish dolerites. Earth and Planetary Science Letters, 35, 92-104.

Perigo, R., VAN Der Voo, R., Auvray, B. \& Bonhommet, N. 1983. Palaeomagnetism of late Precambrian-Cambrian volcanics and intrusives from the Armorican Massif, France. Geophysical Journal of the Royal Astronomical Society, 75, 23560.

Perroud, H. \& VAN der Voo, R. 1985. Paleomagnetism of the late Ordovician Thouars Massif. Vendee Province, France. Journal of Geophysical Research, 90, 4611-25.

Pique, A. 1983. Structural domains of the Hercynian belt in Morocco. NATO ASI Series C, 116, 339-46.

Quinlan, G. H. \& Beaumont, C. 1984. Appalachian thrusting, lithospheric flexure and the Paleozoic stratigraphy of the Eastern interior of North America. Canadian Journal of Earth Sciences, 21, 973-96.

RAO, R. V. \& VAN DER VoO, R. 1980. Paleomagnetism of a Paleozoic anorthosite from the Appalachian Piedmont, Northern Delaware: possible tectonic implications. Earth and Planetary Science Letters, 47, 113-20.

Ross, C. A. 1979. Late Paleozoic collision of North and South America. Geology, 7, 41-4.

RoY, J. L. 1982. Paleomagnetism of Siluro-Devonian rocks from eastern Maine: Discussion. Canadian Journal of Earth Sciences, 19, 225-32.

\& ANDERSON, P. 1981. An investigation of the remanence characteristics of three sedimentary units of the Silurian Mascarene Group of New Brunswick, Canada. Journal of Geophysical Research, 86, 6351-68.

\& MORRIS, W. A. 1983. A review of paleomagnetic results from the Carboniferous of North America; the concept of Carboniferous geomagnetic field horizon markers. Earth and Planetary Science Letters, 65, 167-81

- OPDYKe, N. D. \& IRving, E. 1967. Further paleomagnetic results from the Bloomsburg formation. Journal of Geophysical Research, 72, 507586.

SchmidT, P. W. \& MoRris, W. A. 1977. An alternate view of the Gondwana Paleozoic apparent polar wander path. Canadian Journal of the Earth Sciences, 14, 1674-8.

Smith, A. G. \& Hallam, A. 1970. The fit of the southern continents. Nature, London, 225, 139-44.

Spariosu, D. J. \& Kent, D. V. 1983. Paleomagnetism of the Lower Devonian Traveler Felsite and the Acadian orogeny in the New England Appalachians. Geological Society of America Bulletin, 94, 1319-28.

\& KeNT, D. V. 1984. Devonian APW for North America. Suspect terranes, and the remagnetization hypothesis. EOS, 65, 197 (abstract).

, — \& KePPIE, J. D. 1984. Late Paleozoic motions of the Meguma Terrane, Nova Scotia: new Paleomagnetic evidence. In: VAN DER VoO, R. et al. (eds) Plate Reconstruction from Paleozoic Paleomagnetism. Geodynamics Series, Vol. 12, pp. 82-98, American Geophysical Union, Washington, DC.

Stillman, C. R. \& Francis, E. H. 1979. Caledonide volcanism in Britain and Ireland. In: HARRIS, A. L., Holland, C. H. \& Leake, B. E. (eds) The Caledonides of the British Isles Reviewed. Special Publication of the Geological Society of London No. 8, p. 557.

Thomas, W. A. 1977. Evolution of AppalachianOuachita: salients and recesses from reentrants and promontories in the continental margins. American Journal of Science, 277, 1233-78.

Ueno, H., Irving, E. \& McNutt, R. H. 1975. Paleomagnetism of the Whitestone anarthosite and diorite, the Grenville polar track, and relative motions of the Laurentian and Baltic Shields. Canadian Journal of Earth Sciences, 12, 209-26.

VAN DER VOo, R. 1979. Paleozoic assembly of Pangea: a new plate tectonic model for the Tactonic, Caledonian, and Hercynian orogenies. EOS, 60 , 241.

1982. Pre-Mesozoic Paleomagnetism and plate tectonics. Annual Review of Earth and Planetary Sciences, 10, 191-220.

\& SCOTESE, C. 1981. Paleomagnetic evidence for a large $(2000 \mathrm{~km})$ sinistral offset along the Great Glen fault during Carboniferous time. Geology, 9, 583-9.

- French, A. N. \& French, R. B. 1979. A palaeomagnetic pole position from the folded Upper Devonian Catskill redbeds, and its tectonic implications. Geology, 7, 345-48. 
, Mauk, F. J. \& French, R. B. 1976. PermianTriassic continental configurations and the origin of the Gulf of Mexico. Geology, 4, 177-80.

, Peinado, J. \& Scotese, C. R. 1984. A Paleomagnetic reevaluation of Pangea reconstructions. In: VAN DER VOO, R. et al. (eds) Plate Reconstruction from Paleozoic Paleomagnetism. Geodynamics Se- ries, Vol. 12, pp. 11-26, American Geophysical Union, Washington, D.C.

Young, G. C. 1981. Biogeography of Devonian vertebrates. Alcheringa, 5, 225-43.

ZIEGLER, P. A. 1984. Caledonian and Hercynian crustal consolidation of Western and Central Europe-a working hypothesis. Geologie en Mijnbouw, 63, 93108.

D. V. KENT, Lamont-Doherty Geological Observatory and Department of Geological Sciences, Columbia University, Palisades, NY 10964, USA.

J. D. KEPPIE, Department of Mines and Energy, Halifax, Nova Scotia B3J 2XI, Canada.

\section{Note added in proof}

Since this paper was presented in Glasgow in September 1984, and revised copy accepted for publication in January 1986, new data have become available that in some cases do, but in other cases do not, support the tectonic syntheses presented here. New palaeomagnetic results from Lower Devonian redbeds in the Appalachians place America approximately $15^{\circ}$ farther south than shown in Fig. 1, reducing the latitudinal offset between N America on one side and Baltica as well as Armorica on the other; thus a Pangea B-like assembly may have been approached by early Devonian time with northwestern S America against eastern N America (Miller \& Kent 1987), similar to the configuration suggested previously by McKerrow \& Ziegler (1972), Keppie (1977) and Morel \& Irving (1978). For the late Devonian, the secondary nature of the magnetizations originally reported from the Upper Devonian Catskill redbeds has been confirmed (Miller \& Kent 1986a, b). Nevertheless, palaeomagnetic results from Upper Devonian rocks from western Australia strongly suggest that a wide ocean existed between Gondwana and Euramerica in the late Devonian (Hurley \& Van der Voo 1987); thus Fig. 2 refers more appropriately only to the early Carboniferous. Taken at face value, the palaeomagnetic evidence would now seem to suggest that the Devonian encompassed an interval of ocean closure followed by opening between Gondwana and Euramerica.

\section{References}

Hurley, N. F. \& VAN DER Voo, R. 1987. Paleomagnetism of Upper Devonian reefal limestones, Canning basin, Western Australia. Geological Society of America Bulletin, 98, 138-46.

MCKerRow, W. S. \& Ziegler, A. M. 1972. Palaeozoic oceans. Nature, 240, 92-4.

Miller, J. D. \& Kent D. V. 1986a. Paleomagnetism of the Upper Devonian Catskill Formation from the Southern Limb of the Pennsylvania Salient: Possible evidence of oroclinal rotation. Geophysical
Research Letters, 13, 1173-6.

$-\&-1986$ b. Synfolding and prefolding magnetizations in the Upper Devonian Catskill formation of eastern Pennsylvania: Implications for the tectonic history of Acadia. Journal of Geophysical Research, 91, 12, 791-803.

$\&-1987$. Synfolding and prefolding magnetizations of the lower Devonian Andreas Redbeds, Andreas, PA. EOS, 68, 292. 